\title{
Albumin Synthesis in Premature Infants: Determination of Turnover with $\left[{ }^{15} \mathrm{~N}\right]$ Glycine
}

\author{
MARC YUDKOFF, ITZHAK NISSIM, WENDY MCNELLIS, AND RICHARD POLIN \\ Division of Biochemical Development and Molecular Disease and Division of Neonatology, Children's Hospital \\ of Philadelphia and Department of Pediatrics, University of Pennsylvania School of Medicine, \\ Philadelphia, Pennsylvania 19104
}

\begin{abstract}
Albumin turnover was studied in seven small premature infants who received a constant infusion of $\left[{ }^{15} \mathrm{~N}\right]$ glycine for 60-72 h. Gas chromatography-mass spectrometry was used to measure the rate of appearance of $\left[{ }^{15} \mathrm{~N}\right]$ glycine in albumin isolated from the blood. By comparing the linear increment of $\left[{ }^{15} \mathrm{~N} \mid \mathrm{glycine}\right.$ in blood albumin with plateau labelling of urinary $\left[{ }^{15} \mathrm{~N}\right]$ hippurate, which was assumed to reflect intrahepatic isotopic abundance in $\left[{ }^{15} \mathrm{~N}\right]$ glycine, the fractional synthetic rate for albumin was found to be $0.09-0.177 \mathrm{day}^{-1}$ (mean $\pm \mathrm{SD}=0.122 \pm 0.041$ day $^{-1}$ ). The absolute synthesis rate for albumin was $0.3 \pm$ $0.099 \mathrm{~g} / \mathrm{dl}$ plasma $\cdot \mathrm{day}^{-1}$ and the total plasma synthetic rate was $117.6 \pm 37.0 \mathrm{mg} / \mathrm{kg} \cdot \mathrm{day}^{-1}$. The glycine flux was $326.0-927.7 \mu \mathrm{mol} / \mathrm{kg} \cdot \mathrm{h}^{-1}$ (mean $\pm \mathrm{SD} 516.7 \pm 218.4$ $\mu \mathrm{mol} / \mathrm{kg} \mathrm{hr}^{-1}$ ). The percentage of the glycine flux incorporated into albumin in the total vasculature was $0.425 \pm$ 0.344 . The fractional synthetic rate and the absolute synthetic rate for albumin in these small premature infants are much higher than values obtained in healthy young adults studied with a similar methodology. The relatively low serum albumin concentrations typical of premature infants appear to be referable to more rapid turnover of a small plasma pool rather than a diminution in the rate of albumin synthesis. (Pediatr Res 21: 49-53, 1987)
\end{abstract}

\section{Abbreviations}

FSR, fractional synthetic rate

$\mathrm{Q}_{\mathrm{gly}}$, glycine flux

Serum albumin concentrations in infants vary inversely with the degree of maturity, the blood albumin concentration of the premature newborn being lower than that of the baby born at term (1). It is unknown whether this phenomenon reflects reduced albumin synthesis or increased albumin turnover in less mature babies. A diminished synthetic rate appears to explain the hypoalbuminemia observed in malnourished rats (2-6) and children $(7,8)$. However, such nutritional factors probably do not account for the relatively low albumin of babies whose growth is appropriate for gestational age. Immaturity of hepatic mechanisms subserving albumin synthesis might explain the low albumin. Conversely, the catabolism of albumin might be enhanced, especially in light of the observation that total body protein turnover is inversely related to the degree of maturity of premature infants (9).

We have measured albumin turnover in a group of premature

Received May 27, 1986; accepted August 13, 1986.

Correspondence to Marc Yudkoff, M.D., Children's Hospital of Philadelphia, 34th Street and Civic Center Boulevard. Phladelphia, PA 19104.

Supported by NIH Grants HD 08536, NS17752, and RR00240. babies who received a continuous intravenous infusion of $\left[{ }^{15} \mathrm{~N}\right]$ glycine. The fractional synthetic rate of albumin was determined by comparing the rate of $\left[{ }^{15} \mathrm{~N}\right]$ glycine appearance in serum albumin with the steady state labeling of urinary $\left[{ }^{15} \mathrm{~N}\right]$ hippurate, the latter value being used as a marker of intrahepatic $\left[{ }^{15} \mathrm{~N}\right]$ glycine enrichment $(10,11)$. A modified version of this stable isotope approach was used by Gersovitz et al. (12) to quantitate rates of albumin synthesis in young adults and elderly subejcts.

The results indicate that the relative hypoalbuminemia of premature infants is referable to an enhanced rate of albumin turnover rather than a diminution of albumin synthesis. Indeed, rates of albumin synthesis in these babies are much greater than those reported in the adult, with the albumin half-life in premature babies being less than half the adult value.

\section{MATERIALS AND METHODS}

The $\left[{ }^{15} \mathrm{~N}\right]$ glycine (98 atom \% excess) was purchased from MSD Isotopes, Ltd (Montreal, Canada). The isotope was prepared as a $1 \mathrm{~g} / \mathrm{dl}$ sterile, pyrogen-free solution in $150 \mathrm{mM}$ sodium chloride prior to intravenous administration. The isotope was added to the infants' intravenous solution. Reagents used for derivatization were from Regis Chemical Co. (Chicago, IL). Other reagents were from Fisher Chemical Co. (Silver Springs, MD) and from Sigma Chemical Co. (St. Louis, MO) and were of the highest available grade.

Study design. Seven premature infants were studied. The weight of each was appropriate for gestational age. All were patients in the infant intensive care unit. Both intravenous and intraarterial catheters had been placed for the purpose of clinical management. Thus, no additional infusions or venipunctures were necessary to perform this research, which was approved by the Children's Hospital Committee for the Protection of Human Subjects. None of the infants had any clinical signs of hepatic, renal, or intestinal disease at the time of the study. All of the infants were recovering from respiratory distress syndrome. None of the infants had more than trace amounts of urine protein. Stool losses were nonexistent because the infants received total parenteral nutrition. Clinical details are given in Table 1.

For at least 4 days prior to study the infants received intravenously $80 \mathrm{kcal} / \mathrm{kg} \cdot \mathrm{day}^{-1}$, including approximately $2 \mathrm{~g} / \mathrm{kg} \cdot \mathrm{day}^{-1}$ of lipid (Intralipid; Kabi Vitrum) and $2 \mathrm{~g} / \mathrm{kg} \cdot \mathrm{day}^{-1}$ of amino acids (Trophamine, American McGaw, Glendale, CA).

The study was started after obtaining baseline samples of urine for determination of $\left[{ }^{15} \mathrm{~N}\right]$ hippurate. Baseline samples of blood also were taken for measurement of the albumin concentration and isotopic abundance of $\left[{ }^{15} \mathrm{~N}\right] \mathrm{glycine}$. After the baseline samples were taken, a priming dose of $\left[{ }^{15} \mathrm{~N}\right] \mathrm{glycine}$, either $28 \mu \mathrm{mol} /$ $\mathrm{kg}$ (three subjects) or $56 \mu \mathrm{mol} / \mathrm{kg}$ (four infants), was administered intravenously and was followed by a continuous infusion of $\left[{ }^{15} \mathrm{~N}\right]$ glycine, either $0.4 \mu \mathrm{mol} / \mathrm{kg} \cdot \mathrm{min}^{-1}$ (three infants) or $0.67 \mu \mathrm{mol} /$ $\mathrm{kg} \cdot \mathrm{min}^{-1}$ (four infants) for the next $60-72 \mathrm{~h}$. The data from all 
seven infants are presented together because the dose of isotope did not affect the results.

Urine was collected as voided in plastic devices. The time of each void was recorded and the urine was analyzed for isotopic enrichment in $\left[{ }^{15} \mathrm{~N}\right]$ hippurate. Blood $(1 \mathrm{ml})$ was sampled every $12 \mathrm{~h}$ until $60-72 \mathrm{~h}$. It was placed in heparinized tubes and the plasma separated by centrifugation. All samples were kept at $-80^{\circ} \mathrm{C}$ until analyzed for $\left[{ }^{15} \mathrm{~N}\right]$ glycine.

Determination of $\int^{15} \mathrm{~N} / g l y c i n e$ enrichment of albumin. Albumin was isolated from plasma by ethanol extraction of the plasma proteins which had been precipitated with trichloroacetic acid (13). A single band corresponding to albumin was observed with sodium dodecyl sulfate gel electrophoresis. The albumin was hydrolyzed in $6 \mathrm{~N} \mathrm{HCl}(2 \mathrm{ml})$ at $120^{\circ} \mathrm{C}$ for $20 \mathrm{hr}$. The sample was taken to dryness under $\mathrm{N}_{2}$ and the residue was redissolved in $1 \mathrm{ml}$ of water. This was applied to a $4 \times 0.5 \mathrm{~cm}$ glass column of $\mathrm{AG}-50$ resin $\left(\mathrm{H}^{+} ; \mathrm{X} 8 ; 50-100 \mathrm{mesh}\right)$. After washing with $3 \mathrm{ml}$ of deionized water, the amino acids were eluted with $3 \mathrm{ml}$ of 4 $\mathrm{M} \mathrm{NH}{ }_{4} \mathrm{OH}$. The eluate was dried under $\mathrm{N}_{2}$ and the t-butyldimethylsilyl derivative was prepared prior to gas chromatographymass spectrometry.

Table 1. Clinical summary of infants studied

\begin{tabular}{lcccc}
\hline Patient & $\begin{array}{c}\text { Gestational } \\
\text { age (wk) }\end{array}$ & $\begin{array}{c}\text { Age at } \\
\text { study (days) }\end{array}$ & Wt (kg) & Sex \\
\hline BK & 26 & 7 & 0.89 & M \\
BE & 32 & 7 & 1.20 & M \\
BMcG & 30 & 3 & 1.04 & M \\
DC & 25 & 7 & 0.74 & M \\
CS & 26 & 11 & 0.70 & F \\
JS & 26 & 11 & 0.78 & M \\
JY & 30 & 5 & 0.89 & M \\
\hline
\end{tabular}

Determination of ${ }^{15} \mathrm{~N}$ in blood and urine. For determination of isotopic abundance in urinary $\left[{ }^{15} \mathrm{~N}\right]$ hippuric acid, $0.5 \mathrm{ml}$ of urine was acidifed to $\mathrm{pH} 2-3$ with $1 \mathrm{~N} \mathrm{HCl}$ and applied to a $3 \mathrm{ml} \mathrm{C}$ 18 column (Baker Chemical Co., Phillipsburg, NJ). After washing with deionized water $(3 \mathrm{ml})$, hippurate was eluted with $5 \mathrm{ml}$ acetonitrile. The eluate was taken to dryness under nitrogen and the t-butyldimethylsilyl derivative was prepared.

Gas chromatography-mass spectrometry. Isotopic abundance in derivatized samples was determined on a Hewlett-Packard 5990A GC-MS system. Conditions were injector temperature $250^{\circ} \mathrm{C}$, detector temperature $280^{\circ} \mathrm{C}$, oven temperature program $150^{\circ} \mathrm{C}$ for $1 \mathrm{~min}$, and then $10^{\circ} \mathrm{C} / \mathrm{min}$ until $300^{\circ} \mathrm{C}$. The filament was at $70 \mathrm{eV}$. The electron multiplier was set at $1800-2330 \mathrm{~V}$, depending on sample size.

${ }^{15} \mathrm{~N}$ isotopic abundance was obtained by selected ion monitoring of the $\mathrm{m} / \mathrm{z} 219 / 218$ ratio for glycine and the $\mathrm{m} / \mathrm{z} 207 / 206$ ratio for hippurate.

Isotopic enrichment (atom \% excess) was calculated according to Millard (14).

Metabolite determination. Serum albumin was measured with the bromocresol dye method (15).

Methods of calculation. The FSR for albumin was calculated from:

$$
\text { FSR }\left(\text { day }^{-1}\right)=\Delta I_{\text {alb }} / I_{\text {hipp }} \times 24
$$

where $\Delta \mathbf{I}_{\text {alb }}$ is the rate of linear increment (atom $\%$ excess $/ \mathrm{h}$ ) of isotopic abundance in $\left[{ }^{15} \mathrm{~N}\right]$ glycine in albumin, as determined by linear regression analysis of the data points from $12 \mathrm{~h}$ until the conclusion of the experiment $(60-72 \mathrm{~h})$, and $\mathrm{I}_{\text {hipp }}$ is the steadystate enrichment (atom \% excess) in $\left[{ }^{15} \mathrm{~N}\right]$ hippuric acid.

The steady state labeling of $\left[{ }^{15} \mathrm{~N}\right]$ hippuric acid was calculated by computer fitting of the curves of isotopic abundance in urinary $\left[{ }^{15} \mathrm{~N}\right]$ hippurate to the expression: $\mathrm{A}+\mathrm{Be}^{-\mathrm{kt}}$, where the plateau
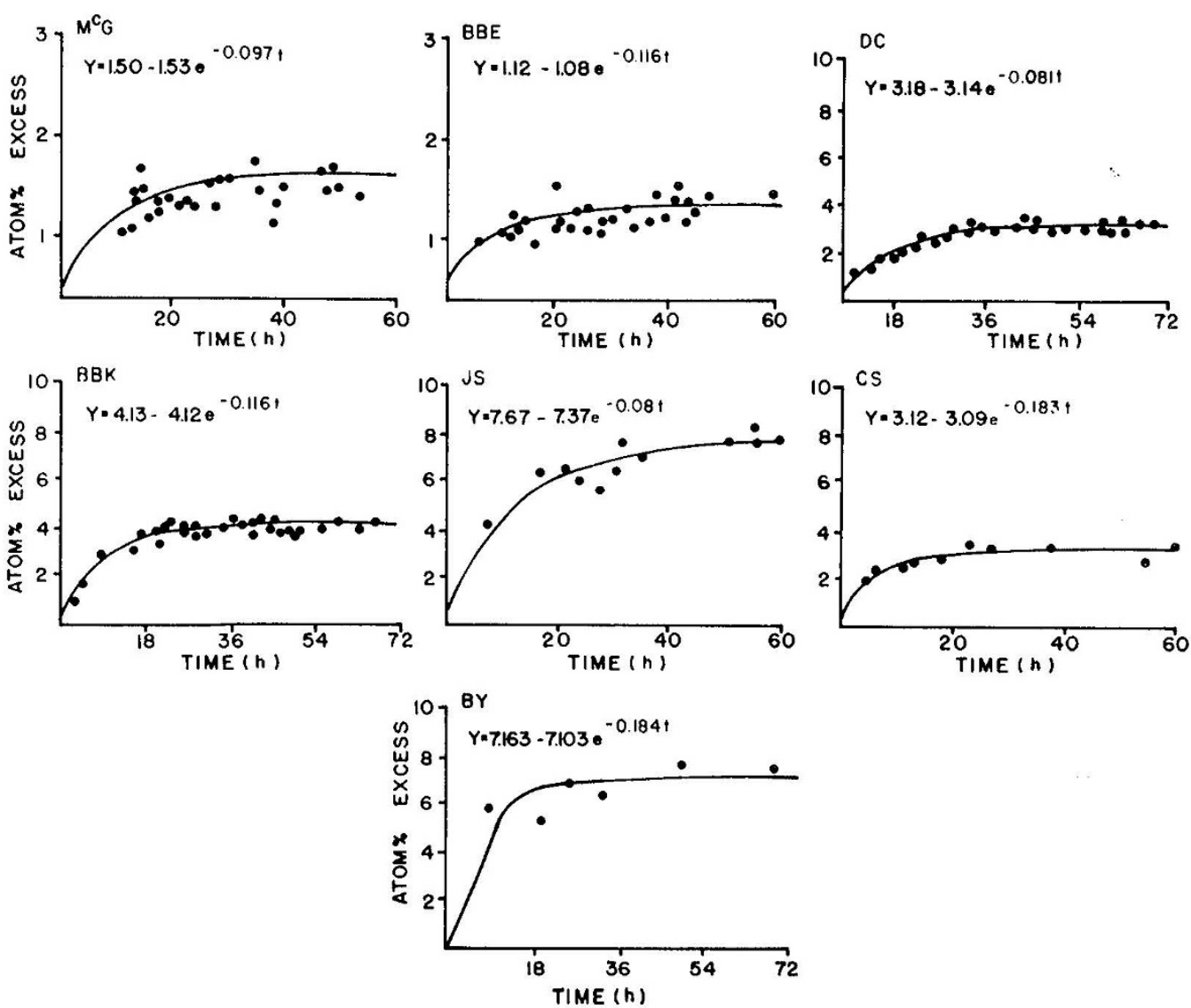

Fig. 1. The appearance (atom \% excess) versus time of $\left[{ }^{15} \mathrm{~N}\right]$ hippuric acid in urine in premature infants receiving an intravenous infusion of $\left[{ }^{15} \mathrm{~N}\right]$ glycine. 
level of enrichment (atom \% excess) is $A$ at $t_{\infty}$ and the value of $B$ is negative.

The plasma albumin synthesis rate $\left(\mathrm{g} / \mathrm{dl} \cdot \mathrm{day}^{-1}\right)$ was calculated from the product of the serum albumin and the FSR. The rate of total intravascular albumin synthesis was calculated by assuming the plasma volume to be $4 \%$ of body weight (16) and multiplying total plasma albumin by the plasma albumin synthesis rate.

The $\left(Q_{\text {gly }}\right.$ was calculated from

$$
\mathrm{Q}_{\mathrm{gly}}\left(\mu \mathrm{mol} / \mathrm{kg} \cdot \mathrm{h}^{-1}\right)=100\left(\frac{\mathrm{d}}{\mathrm{I}_{\mathrm{gly}}}\right)-\mathrm{d}
$$

where $\mathrm{d}$ is the isotope infusion rate $\left(\mu \mathrm{mol} / \mathrm{kg} \cdot \mathrm{h}^{-1}\right)$ and $\mathrm{I}_{\text {gly }}$ is the steady state isotopic abundance in blood $\left[{ }^{15} \mathrm{~N}\right]$ glycine.

\section{RESULTS}

In Figure 1 are shown data for the appearance of $\left[{ }^{15} \mathrm{~N}\right]$ hippuric acid in the urine of the seven infants studied. In each instance a steady-state with respect to isotopic abundance was attained no later than $20 \mathrm{~h}$ after the start of the $\left[{ }^{15} \mathrm{~N}\right]$ glycine infusion. A plateau level of labeling in $\left[{ }^{15} \mathrm{~N}\right]$ hippurate probably was attained in the liver much sooner, but could not be appreciated from the urinary data because of the relatively low glomerular filtration rate in these immature babies. For this reason, the data points representing the appearance of $\left[{ }^{15} \mathrm{~N}\right]$ glycine in albumin from 12 $h$ until the end of the experiment were used to estimate by linear regression the initial rate of incorporation of labeled glycine in albumin.

The appearance of $\left[{ }^{15} \mathrm{~N}\right]$ glycine in albumin is illustrated by the data in Figure 2. In each study the initial rate of incorporation was linear during the period of observation. As shown in Table 2 , the serum albumin concentrations were lower than those anticipated in term infants $(2.32 \pm 0.48$ versus $3.6 \pm 0.5 \mathrm{~g} / \mathrm{dl})$ (17). Comparable values for the serum albumin concentration in premature infants of this weight have been reported by others (1). The fractional synthetic rates $\left(\mathrm{day}^{-1}\right)$ ranged between 0.059 0.177 , corresponding to albumin half-lives of 3.9-11.7 days. The total plasma synthetic rates, referring to albumin present in the intravascular space, were $62.4-161.0 \mathrm{mg} / \mathrm{kg} \cdot$ day $^{-1}$.

No correlation could be identified between the albumin fractional synthetic rate and gestational age or weight.

Values for $\mathrm{Q}_{\mathrm{gly}}$ and the fraction of $\mathrm{Q}_{\mathrm{gly}}$ incorported into albumin in the intravascular space are given in Table $3 . Q_{g l y}$ of these infants $\left(516.7 \pm 218.4 \mu \mathrm{mol} / \mathrm{kg} \cdot \mathrm{h}^{-1}\right)$ was higher than comparable values in the healthy postabsorptive adult $(18,19)$, a finding similar to that reported previously by others (20). Less than $0.5 \%$ of the glycine flux represents glycine incorporated into intravascular albumin. Total body albumin synthesis could not be estimated because the precise albumin distribution volume in these premature babies is unknown. However, even if the albumin distribution space were much greater than the intravascular space, as it is in the adult (21), it is evident that only a very small fraction of $\mathrm{Q}_{\mathrm{gly}}$ would have been incorporated into albumin in these infants.

\section{DISCUSSION}

Albumin turnover in premature infants was studied by administering a constant $\left[{ }^{15} \mathrm{~N}\right]$ glycine infusion and utilizing gas chromatography-mass spectrometry to measure appearance of this isotope in blood albumin. By comparing the linear rate of increment of $\left[{ }^{15} \mathrm{~N}\right]$ glycine in albumin with the steady-state enrichment of urinary $\left[{ }^{15} \mathrm{~N}\right]$ hippurate, which was assumed to represent the intrahepatic enrichment of $\left[{ }^{15} \mathrm{~N}\right]$ glycine, the FSR for albumin was calculated.
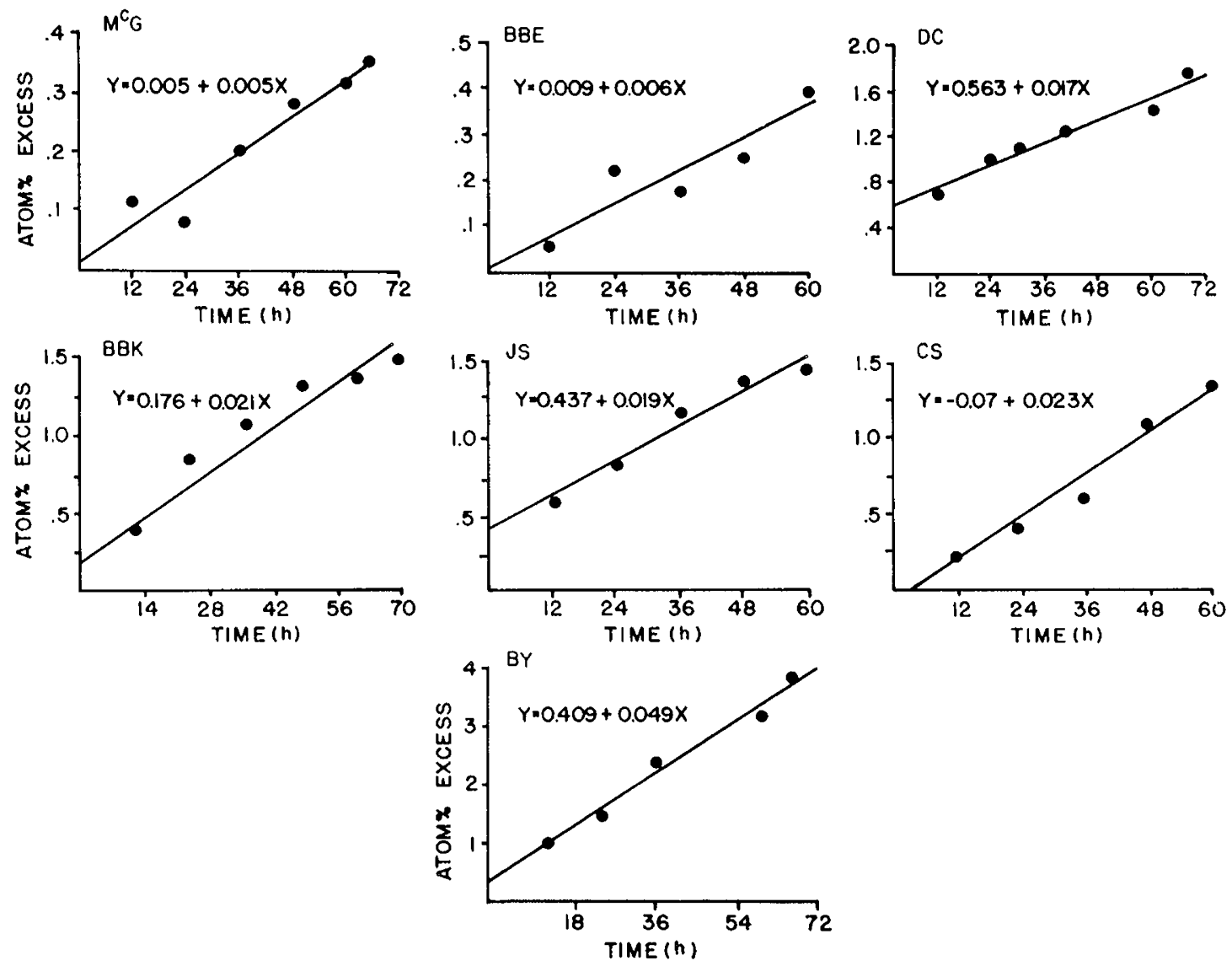

Fig. 2. The appearance (atom \% excess) versus time of $\left[{ }^{15} \mathrm{~N}\right]$ glycine in blood albumin of premature infants receiving an intravenous infusion of $\left[{ }^{15} \mathrm{~N}\right] g l y c i n c$. 
Table 2. Albumin synthetic parameters

\begin{tabular}{lccrr}
\hline Patient & $\begin{array}{c}\text { Serum albumin } \\
(\mathrm{g} / \mathrm{dl})\end{array}$ & $\begin{array}{c}\text { FSR } \\
\left(\text { day }^{-1}\right)\end{array}$ & $\begin{array}{c}\text { Synthesis rate } \\
(\mathrm{g} / \mathrm{dl} \cdot \text { day })^{-1}\end{array}$ & $\begin{array}{c}\text { Total plasma synthesis rate } \\
\left(\mathrm{mg} / \mathrm{kg}_{\mathrm{day}} \mathbf{d}^{-1}\right)\end{array}$ \\
\hline BK & 2.40 & 0.122 & 0.292 & 117.0 \\
BE & 3.12 & 0.130 & 0.406 & 162.0 \\
BMcG & 2.54 & 0.080 & 0.203 & 81.2 \\
DC & 2.10 & 0.128 & 0.268 & 107.2 \\
CS & 1.60 & 0.177 & 0.381 & 152.4 \\
JS & 2.00 & 0.059 & 0.156 & 62.4 \\
BY & 2.50 & 0.159 & 0.397 & 141.3
\end{tabular}

Mean \pm SD

$2.32 \pm 0.48$

$0.122 \pm 0.041$

$0.300 \pm 0.099$

$117.6 \pm 37.0$

Table 3. $Q_{k l \cdot}$ and fraction (\%) of $Q_{k l \cdot}$ utilized for total plasma albumin synthesis

\begin{tabular}{lcc}
\hline Patient & $\mathrm{Q}_{\mathrm{gly}}\left(\mu \mathrm{mol} / \mathrm{kg} \cdot \mathrm{h}^{-1}\right)$ & Fx. (\%) $\mathrm{Q}_{\mathrm{gly}}$ in albumin* \\
\hline BK & 330.5 & 0.409 \\
$\mathrm{BE}$ & 544.9 & 0.343 \\
$\mathrm{BMcG}$ & 447.2 & 1.154 \\
$\mathrm{DC}$ & 662.8 & 0.187 \\
$\mathrm{CS}$ & 927.7 & 0.190 \\
JS & 377.5 & 0.190 \\
BY & 326.0 & 0.500
\end{tabular}

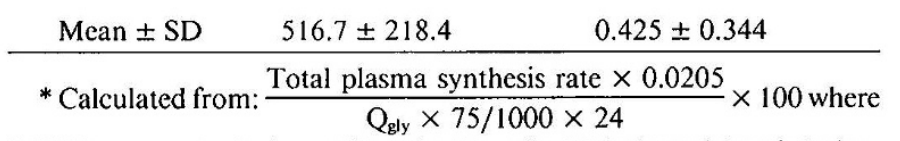

0.0205 represents glycine residues in albumin, 75 is the weight of glycine, 1000 converts from micromoles and 24 converts to day ${ }^{-1}$.

This technique entails several assumptions. The most important of these is that urinary $\left[{ }^{15} \mathrm{~N}\right]$ hippurate enrichment accurately reflects steady-state isotopic abundance of liver $\left[{ }^{15} \mathrm{~N}\right]$ glycine. Rigorous validation of this assumption would require the direct determination of $\left[{ }^{15} \mathrm{~N}\right]$ glycine bound to hepatic t-RNA. Although such demonstration clearly is impossible in the human neonate, available evidence suggests that steady-state labeling of urinary $\left[{ }^{15} \mathrm{~N}\right]$ hippurate can be used in this way. Weissman et al. (22) administered both $\left[{ }^{15} \mathrm{~N}\right]$ glycine and $\left[{ }^{14} \mathrm{C}\right]$ glycine to adults and compared values for albumin synthesis based on urinary $\left[{ }^{15} \mathrm{~N}\right]$ hippurate data as well as the decay curves of plasma $\left[{ }^{14} \mathrm{C}\right]$ albumin. The concordance of results obtained by these two disparate methods suggested that enrichment of hippurate nitrogen is a good marker for enrichment of hepatic glycine nitrogen. Studies of $\left[{ }^{15} \mathrm{~N}\right]$ urate synthesis following the intravenous administration of $\left[{ }^{15} \mathrm{~N}\right] g l y c i n e$ also indicate close agreement between decay curves of urinary hippurate and plasma glycine (23-25). Cryer et al. (26) recently found that the steady-state labeling of $\left[{ }^{15} \mathrm{~N}\right]$ glycine in apolipoprotein $\mathrm{B}$, which is synthesized only in the liver, is very similar to that of urinary $\left[{ }^{15} \mathrm{~N}\right]$ hippurate in healthy adults receiving a constant infusion of $\left[{ }^{15} \mathrm{~N}\right] \mathrm{glycine}$.

The current method also assumes that hepatic $\left[{ }^{15} \mathrm{~N}\right]$ hippurate enrichment is constant when measurements are made of the increase of $\left[{ }^{15} \mathrm{~N}\right]$ glycine in albumin. We utilized the time points from $12 \mathrm{~h}$ until the end of the study to calculate enrichment of serum albumin with $\left[{ }^{15} \mathrm{~N}\right]$ glycine. In the adult mixing of the $\left[{ }^{15} \mathrm{~N}\right]$ hippurate pool should be complete by $12 \mathrm{~h}(27)$. In the premature infant, whose glomerular filtration rate is relatively low, a steady-state with respect to labeling of hepatic $\left[{ }^{15} \mathrm{~N}\right]$ hippurate probably existed by $12 \mathrm{~h}$ but may not have become manifest in measurements made in urine. The fact that enrichment of $\left[{ }^{15} \mathrm{~N}\right]$ glycine in albumin increased linearly after $12 \mathrm{~h}$ (Fig. 2) suggests that steady-state conditions obtained in the liver before a plateau of urinary $\left[{ }^{15} \mathrm{~N}\right]$ hippurate was noted. The final result for FSR would not have been altered substantially by waiting longer than $12 \mathrm{~h}$ to make the initial measurement.
The method also assumes negligible reentry of $\left[{ }^{15} \mathrm{~N}\right]$ glycine from the catabolism of albumin. As indicated by the data of Table 2, a trivial portion of $\mathrm{Q}_{\text {gly }}$ is directed into the synthesis of albumin. This would be the case even if the total body albumin pool were four or five times the size of the intravascular pool. Significant reentry of $\left[{ }^{15} \mathrm{~N}\right]$ glycine from albumin into the amino acid pool utilized for protein synthesis must therefore be minimal.

The FSR, as determined from the $\left[{ }^{15} \mathrm{~N}\right]$ glycine data, is much greater in premature infants than in adults studied with a similar methodology (12). Thus, the mean value for FSR was 0.122 day $^{-1}$ in the infants and $0.03-0.04$ day $^{-1}$ in healthy young adults (see Table 2) (12). The absolute plasma synthetic rate also is substantially higher in premature infants than in adults: 0.3 versus $0.12-0.16 \mathrm{~g} / \mathrm{dl} \cdot \mathrm{day}^{-1}$, assuming a mean serum albumin in the adults of $4 \mathrm{~g} / \mathrm{dl}$ (12). A relatively high rate of albumin synthesis in the newborn corresponds with the finding that the rates of total body protein synthesis and degradation vary inversely with age throughout the human life span, being especially high in premature infants $(9,28,29)$. The relatively low concentration of blood albumin in prematures (Table 2), therefore, does not appear to be referable to a diminished rate of synthesis, but to the more active turnover of the relatively small plasma pool.

The precise determination of the albumin distribution volume would require the parenteral administration of radiolabeled albumin in order to develop a decay curve from which the albumin pool size could be described. In infants this approach clearly is impossible, and the distribution volume and total body albumin synthesis rate cannot be determined unequivocally. We estimated the total plasma synthesis rate (Table 2) by utilizing the data of Friis-Hansen (16) to calculate the plasma volume. In adults only $31-42 \%$ of the exchangeable albumin pool is located in the plasma compartment (30). An additional pool, localized to skin and muscle, is characterized by a much slower turnover rate ( 31 , 32). The exchangeable albumin pool of the newborn, in whom the extracellular fluid constitutes a relatively large fraction of body weight (16), undoubtedly extends beyond the intravascular albumin pool. Evidence for this is the observation that more than two-thirds of albumin administered to infants as treatment of hyperbilirubinemia diffuses into the extravascular space within 2-3 h $(33,34)$.

If we assume, for the purpose of approximation, that in our study population $25 \%$ of body albumin is present in the vasculature, then the mean value for total body albumin synthesis would be about $500 \mathrm{mg} / \mathrm{kg}$. day ${ }^{-1}$. Since the rate of whole body protein synthesis in infants of this size is between $5-13 \mathrm{~g} / \mathrm{kg}$. day $^{-1}(9,28)$, it follows that albumin production accounts for 4 $10 \%$ of overall protein synthesis. This fraction is comparable to that of the adult, in whom albumin synthesis is $120-200 \mathrm{mg} / \mathrm{kg}$. day $^{-1}(30)$ and the rate of body protein synthesis is estimated to be $2-3 \mathrm{~g} / \mathrm{kg} \cdot$ day $^{-1}(35)$.

The reason for increased albumin synthesis in these infants cannot be determined with certainty from the present data. Synthesis conceivably could be enhanced in response to unusual losses from the body, but only trace amounts of protein were 
present in the urine and stool losses were nil in these babies receiving total parenteral nutrition.

Nor are nutritional factors a likely explanation for the enhanced albumin turnover. The intake of amino acids and energy was $2 \mathrm{~g} / \mathrm{kg} \cdot \mathrm{day}^{-1}$ and $80 \mathrm{kcal} / \mathrm{kg} \cdot \mathrm{day}^{-1}$. Each value is lower than the estimated nutritional requirement for premature infants (36), although each is typical of the short-term nutritional support offered to infants recovering from hyaline membrane disease and receiving nourishment via a peripheral vein. Substantial evidence from both in vivo and in vitro studies suggests that malnutrition or undernutrition is associated with diminished albumin turnover, not the augmented FSR observed in this investigation (2-8). The available data suggest that the FSR could have been even greater if the infants had received more amino acids and total calories.

Rather than being the result of nutritional factors, the relatively high albumin synthesis rate probably is referable to the more generalized intensification of whole body protein turnover which is characteristic of such small infants $(9,28,29)$. Indeed, Nissim et al. (9) found that protein turnover may be inversely related to gestational age. The concept of whole body protein turnover is necessarily artificial because it represents the integral of many different protein pools, each of which has a unique rate of metabolism (35). Nor is it certain that maturational changes in the kinetics of individual protein pools must be similar, as is evidenced by the differing patterns of excretion of 3-methylhistidine and dimethylarginine in human prematures $(9,27)$. The current data show that turnover of the blood albumin pool is, indeed, very high in premature babies.

A great deal of additional investigation regarding albumin turnover in infants is needed. The relationship between this kinetic parameter and such variables as dietary intake, the degree of maturity, and anthropometric data are of interest. Raiha et al. (38) found that the blood albumin concentration in babies receiving a formula containing $3.0 \mathrm{~g}$ protein/dl exceeded that of a group receiving either breast milk or a preparation containing $1.5 \mathrm{~g} / \mathrm{dl}$. Although such studies improve our understanding of the nutritional requirements of infants, the determination of a serum protein concentration alone provides no information with respect to the mechanism underlying an increase or decrease of the blood level. Such kinetic data can only be obtained with an isotopic technique similar to the one described in this investigation. The current method is safe, involving the use of stable isotopes only, and does not invoke the use of a complex experimental design. The amounts of blood necessary to perform the study are small enough that measurements can be made of albumin turnover in even the smallest premature babies.

Acknowlegments. The authors thank Rosemary Aversa, Denise Denner, and Ilana Nissim for their expert technical assistance and Joan Kubinski for typing the manuscript.

\section{REFERENCES}

1. Saito M. Gittleman IF. Pincus JB. Sobel AE 1956 Plasma protein patterns in premature infants of varying weights on the first day of life. Pediatrics 17:657-66!

2. Kirsch R. Frith L, Black E, Hoffenberg R 1968 Regulation of albumin synthesis and catabolism by alteration of dietary protein. Nature 217:578-579

3. Kirsch RE. Saunders SJ, Frith L, Wicht S, Kelman L, Brock JF 1969 Plasma amino acid concentration and the regulation of albumin synthesis. Am J Clin Nutr 22:1559-1562

4. Haider M. Tarver H 1969 Effect of diet on protein synthesis and nucleic acid levels in rat liver. J Nutr 99:433-445

5. Morgan EH, Peters T Jr 1971 The biosynthesis of rat serum albumin. V, Effect of prolonged depletion and refeeding on albumin and transferrin synthesis. J Biol Chem 246:3500-3507

6. Kelman L, Saunders SJ, Wicht S, Frith L, Corrigall A, Kirsch RE, Terblanche J 1972 The effects of amino acids on albumin synthesis by the isolated perfused rat liver. Biochem J 129:805-809

7. Cohen S, Hansen JDL 1962 Metabolism of albumin and globulin in kwashior- kor. Clin Sci 23:351-359

8. James WPT, Hay AM 1968 Albumin metabolism: Effect of the nutritional state and the dietary protein intake. J Clin Invest 47:1958-1972

9. Nissim I, Yudkoff M, Pereira G, Segal S 1983 Effects of conceptual age and dietary intake on protein metabolism in premature infants. J Pediatr Gastroenterol Nutr 2:507-516

10. Stein TP, Leskiw MJ, Wallace HW, Blakemore WS 1976 The use of a continuous infusion of ${ }^{15} \mathrm{~N}$ for the study of human nitrogen metabolism. In: Bianchi R, Mariani G, McFarlane AS (eds) Plasma Protein Turnover. University Park Press, Baltimore, pp 219-235

11. Stein TP, Leskiw MJ, Wallace HW 1978 Measurement of half-life of human fibrinogen. Am J Physiol 234:E504-E510

12. Gersovitz M, Munro HN, Udall J, Young VR 1980 Albumin synthesis in young and elderly subjects using a new stable isotope methodology: response to level of protein intake. Metabolism 29:1075-1086

13. Korner A, Debro JR 1956 Solubility of albumin in alcohol after precipitation by trichloroacetic acid: a simplified procedure for separation of serum albumin. Nature 178:1067

14. Millard BJ 1979 Quantitative Mass Spectrometry. Heyden \& Son, Ltd, London, p $71-74$

15. Cannon DG, Olitzky I, Inkpen JA 1974 Proteins. In Henry RJ, Cannon DC, Winkelman HA (eds) Clinical Chemistry Principles and Techniques. Harper and Row, New York, pp 440

16. Friis-Hansen B 1964 Body water compartments in children: changes during growth and related changes in body composition. Pediatrics 28:169-181

17. Wood B, Comley A, Sherwell J 1970 Effect of additional albumin administration during exchange transfusion on plasma albumin-binding capacity. Arch Dis Child 45:59-62

18. Nissim I, Yudkoff M, Segal S 1983 A model for determination of total body protein synthesis based upon compartmental analysis of the plasma [ $\left.{ }^{15} \mathrm{~N}\right]$ glycine decay curves. Metabolism 32:646-653

19. Yudkoff M, Nissim I, Glassman M, Segal S 1984 Whole body nitrogen kinetics in man: determination from plasma [guanidino ${ }^{15} \mathrm{~N}$ ]arginine. Clin Sci 66:337-342

20. Lapidot A, Nissim I 1980 Application of nitrogen-15 GC-MS in metabolic studies of amino acids in man. In: Quayle A (ed) Advances in Mass Spectrometry. Heyden, London, pp 1142-1154

21. Peters T 1975 Serum albumin. In: Putnam FW (ed) The Plasma Proteins: Structure, Function and Genetic Control, Vol 1. New York, Academic Press, pp 133-181

22. Weissman S, Tschudy DP, Bacchus H, Eubanks M 1961 Use of precursor product relationships in determining serum albumin half-life. $\mathrm{J}$ Lab Clin Med 57:136-146

23. Howell RR, Speas M, Wyngaarden JB 1961 A quantitative study of recycling of isotope from glycine- $1-{ }^{14} \mathrm{C}, \alpha-{ }^{15} \mathrm{~N}$ into various subunits of the uric acid molecule. J Clin Invest 40:2076-2082

24. Sperling O, Wyngaarden JB, Starmer CF 1973 The kinetics of intramolecular distribution of ${ }^{15} \mathrm{~N}$ in uric acid after administration of $\left[{ }^{15} \mathrm{~N}\right]$ glycine. $J$ Clin Invest 52:2468-2485

25. Watts RWE, Crawhall JC 1959 The first glycine metabolic pool in man. Biochem J 73:273-286

26. Cryer DR, Matsushima T, Marsh JB, Yudkoff M, Coates PM, Cortner JA 1986 Direct measurement of apolipoprotein B synthesis in human very low density lipoportein using stable isotopes and mass spectrometry. $\mathrm{J}$ Lipid Res 27:508-516

27. Stein TP, Leskiw MJ, Wallace HW 1976 Equilibration of ${ }^{15} \mathrm{~N}$ labeled amino compounds in man. Am J Physiol 230:1326-1330

28. Nicholson JF 1970 Rates of protein synthesis in premature infants. Pediatr Res 4:389-404

29. Pencharz PB, Fairi L, Papageorgiu A 1983 The effects of human milk and low protein formulae on the rates of total body protein turnover and urinary 3methylhistidine excretion of preterm infants. Clin Sci 64:611-616

30. Rothschild MA, Oratz M, Schreiber SS 1977 Albumin synthesis. In Rosenoer VM, Oratz M, Rothschild MA (eds) Albumin Structure Function and Uses. Pergamon Press, Oxford, pp 227-253

31. Rothschild MA, Bauman A, Yalow RS, Berson SA 1955 Tissue distribution of $\mathrm{I}^{131}$ labeled human serum albumin following intravenous administration. $\mathrm{J}$ Clin Invest 34:1354-1358

32. Rothing $\mathrm{N} 1967$ The normal metabolism of ${ }^{131}$ I-labeled albumin in man. Clin Sci 33:593-602

33. Tsao YC, Yu VYH 1972 Albumin in management of neonatal hyperbilirubinemia. Arch Dis Child 47:250-256

34. Kagan BM, Stanincova V, Felix NS, Hodgman B, Kalman D 1972 Body composition of premature infants: relation to nutrition. Am $\mathrm{J}$ Clin Nutr 25:1153-1164

35. Waterlow JC, Garlick PJ, Millward DJ 1978 Protein Turnover in Mammalian Tissues and in the Whole Body. North-Holland Publishing, Amsterdam, pp 443-481

36. Gross SJ 1983 Growth and biochemical response of preterm infants fed human milk or modified infant formula. N Engl J Med 308:237-241

37. Yudkoff M, Nissim I, Pereira G, Segal S 1984 Urinary excretion of dimethylarginines in premature infants. Biochem Med 32:242-251

38. Raiha NCR, Heinonen K, Rassin DK, Gaull GE 1976 Milk protein quality in low-birth weight infants. I. Metabolic responses and effects on growth, Pediatrics 57:659-674 